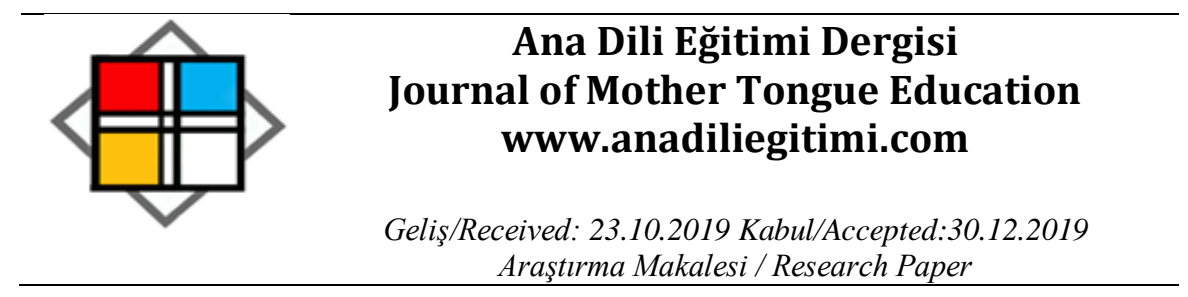

\title{
2010-2019 Yükseköğretime Geçiş Sınavlarında Noktalama İşaretlerinin Kullanımı Bilgisini Yoklayan Soruların İncelenmesi
}

\author{
Mahir KALFA* \\ Merve $\mathrm{AVCl}^{* *}$
}

\begin{abstract}
Öz
Türkçede noktalama işaretleri, dil bilgisi konuları arasında en az ele alınan ve hatta incelemeye bile değer bulunmayan bir bölümdür. Türkçede noktalamanın görüldüğü ve noktalama hakkında ilk bilgilerin yer aldığı metin, Şinasi'nin Şair Evlenmesi adlı oyunudur. Şemseddin Sami tarafından kaleme alınan Usul-i Tenkit ve Tertip adlı eser bu konu hakkında ayrıntılı bilgi veren Türkçenin ilk önemli çalışmasıdır. Bu çalışma sonraki yıllarda pek çok araştırmaya ışık tutacak niteliktedir. Batıda kullanılan birçok işarete bu eserde yer verilmiştir. Daha sonra yayımlanan yazım kılavuzları bu çalışmayı esas almıştır denebilir. Bu araştırmada Türk Dil Kurumunca yayımlanan 2012 Yazım Kılavuzu esas alınmıştır. Bu kılavuz temel alınarak Türkiye'de yükseköğretim kurumlarına geçiş aşamasında uygulanan merkezî sınavlardan 2010-2019 yılları arasında yapılan sınavlarda noktalama işaretlerinin kullanımını ölçen soruların dağılımı ve ölçülmek istenen özellikleri incelenmiştir. Bu araştırmada sınavlarda noktalama işaretlerini sorgulayan soru sayısı belirlenmiş, hangi noktalama işaretlerinin sorulduğu tespit edilmiştir. Söz konusu sınavlarda yer alan noktalama işaretlerine dair sorularda virgül, üç nokta ve iki noktaya sıklıkla yer verildiği kısa çizgiye hiç yer verilmediği kesme işaretine ise bir kez yer verildiği belirlenmiştir.
\end{abstract}

Anahtar Kelimeler: noktalama, noktalama işaretleri, yükseköğretime geçiş sınavı

\section{A Study on the Questions Examining the Use of Punctuation Marks in the Higher Education Entrance Exams between 2010-2019}

\begin{abstract}
Punctuation marks in Turkish are among the least discussed grammatical subjects, and are not even considered worth examining. In Turkish, the use of punctuation and information about it was first observed in Şinasi's play "Şair Evlenmesi." The work titled "Usul-i Tenkit and Tertip," written by Şemseddin Sami, was the first important work in Turkish. It gave detailed information punctuation, and shed light on further studies in the following years. Many marks used in the West were included in this work. We can say that the spelling guides published later were based on it. The present study was based on Spelling Guide published by the Turkish Language Association, 2012. Based on this guide, the distribution of the questions measuring the use of punctuation marks, and the aspects which those questions were measuring were investigated. It was found that comma, ellipsis dots and colon were frequently used in the questions about punctuation marks in the exams, and hyphen was not used at all, and the apostrophe was used once.
\end{abstract}

Keywords: punctuation, punctuation marks, higher education entrance exam

\footnotetext{
* Doç.Dr., Hacettepe Üniversitesi, Eğitim Fakültesi, Türkçe ve Sosyal Bilimler Eğitimi Bölümü, Ankara, mahirkalfa@hotmail.com, ORCID: 0000-0002-5986-1206

${ }^{* *}$ Arş. Gör., Hacettepe Üniversitesi, Eğitim Fakültesi, Türkçe ve Sosyal Bilimler Eğitimi Bölümü, Ankara, merve_avci@hacettepe.edu.tr ,ORCID: 0000-0002-4007-558X
} 


\section{Giriş}

Dil kişinin düşünme sistemini düzenlemede ve kişilerarası iletişimi sağlamada temel araç görevi görmektedir. Aksan (2015: 51)'e göre "Dil (langue) terimiyle herhangi bir toplumun, ulusun bireyleri arasında anlaşma sağlayan yerleşik dizge anlatılır. Çocuğun konuşmaya başladığı sırada annesinden, aile çevresinden öğrendiği ana dili kuşaktan kuşağa aktarılan, ulusun kültürüyle sıkı sıkıya ilişkili bir bildirişme dizgesidir; toplumsal bir kurumdur." Aktaş (2010: 39)'a göre de bu beceriyi kullanırken "insana, topluma, varlığa, zamana, mekâna ait birçok husus üst üste çakışır, sözde ve seste görünmez çizgiler hâlinde varlıklarını anlaşılmaz biçimde sürdürürler. Konuşma anının sentezi yoktur, o bütün hâlinde anlaşılmalıdır." Konuşmanın yazıya aktarımında bu bütünlüğü sağlayan ise sözcükler arasındaki boşlukların anlamını düzenleyen noktalama işaretleridir.

Noktalama işaretleri sözlü olarak vurgu ve tonlama ile kazandırılan anlamların yazıya aktarımını sağlayan araçlardır. Metnin okunuşuna yön verirler. Cümle bitişi, duraksama, soru sorma, şaşırma, kızma gibi durum ve düşünce bildiren sözleri yazıda gösterebilmeyi sağlarlar. Noktalama kurallarının varlığı ve tutarlılı̆ı söylenişteki etkiyi yazıda standartlaştırmayı da beraberinde getirir. Türk Dil Kurumu Yazım Kılavuzundaki (TDK, 2012; 27) tanıma göre noktalama işaretleri; "duygu ve düşünceleri daha açık ifade etmek, cümlenin yapısını ve duraklama noktalarını belirlemek, okumayı ve anlamayı kolaylaştırmak, sözün vurgu ve ton özelliklerini belirtmek üzere kullanılır."

Türkçede noktalama işaretlerinin ilk kez kullanıldığı metin Şinasi'nin Şair Evlenmesi (1860) adlı eseridir. Şemseddin Sami'nin Usul-i Tenkit ve Tertip (1887) adlı eseri ise noktalama işaretlerinin özellikleri ve kullanım yerleri konusunda bilgi veren ilk çalışmadır. Kalfa (2017: 25), bu eserde noktalama işaretlerinin "dönemine göre ayrıntılı sayılabilecek bir ölçüde ve günümüz noktalamasının tarihsel akışına ışık tutabilecek bir biçimde" incelendiğini söylemiş̧ir. Noktalama işaretleri dil bilgisi konuları içinde belki de en ihmal edilenidir. 1941 yılı yazım kılavuzunda "Noktalama işaretleri, imlâ kuralları içinde değildir. Birçok yerlerden gösterilen istek üzerine yalnız bilgi olmak üzere ana hatları buraya yazılmıştır." (Yazım Kılavuzu, 1941; Kalfa 2017) dipnotu ile yer verilmiştir. Burada noktalama işaretleri nokta, virgül, noktalı virgül, iki nokta, sıra noktalar (üç nokta), nida veya ünlem işareti, soru işareti, çizgi, tırnak işareti, parantez veya ayraç, köşeli parantez ve paragraf veya çengel olarak listelenmiş ve bunların kullanıldığı yerler açıklanmıştır (Yazım Kılavuzu, 1941).

Türkçede noktalama ile ilgili yapılan çalışmalar incelendiğinde en kapsamlı çalışmaların Atasoy (2010) ve Kalfa'ya (2017) ait çalışmalar olduğu görülmektedir. Faysal Okan Atasoy (2010), 2009 yılında yapmış olduğu "Türkçede Noktalama: Sorunlar, Çözümler, Teklifler" başılılı doktora tezi kapsamında bir kitap ve bir makale hazırlamıştır. Kitap, üç ana bölümden oluşmaktadır: giriş, noktalama ile ilgili çalışmalar ve noktalama işaretleri. Birinci bölümde noktalama işaretlerinin tarihsel süreçleri, dil bilgisi öğretimindeki sorunlar ve noktalama sorunları; ikinci bölümde yapılan çalışmaların içeriği ve üçüncü bölümde de noktalama işaretleri ile bu işaretlerin kullanım yerleri, sorunları ve bu sorunlara yönelik çözümler anlatılmaktadır. Yine aynı tezden üretilen "Noktalama İşaretlerinin Tarihi" (Atasoy, 2010) başlıklı makalede de noktalama işaretlerinin kullanılmaya başlanmasının gerekçeleri ile tarihî süreçlerinden bahsedilmiş; bu konuda yapılan çalışmalara değinilmiştir. Kalfa (2017) da Başlangıçtan Günümüze Türkçede Noktalama isimli çalışmasında Türkçenin tarihî dönemlerinden başlayarak günümüz noktalama işaretlerinin başlangıcı olarak görülen Şemsettin Sami'nin Usûl-i Tenkit ve Tertip isimli eserindeki noktalama işaretlerine değinmiş ve bugüne kadar yayımlanmış yazım kılavuzlarında yer alan noktalama işaretleri hakkındaki bilgileri aktarmıştır.

Bu konu ile ilgili yapılan diğer akademik çalışmalara bakıldığında, ağırlıklı olarak ilköğretim 1. ve 2. kademedeki öğrenciler ile ilgili olarak uygulamalı çalışmalar yapıldığı (Alver, Ş ve Sancak, M. 2015; Bağcı, H. 2011; Mataracı, E. 1998; Özkara, Y. Ve İzci, G. 2013; Özcan, Ş. ve Yönez, H. 2018), lisansüstü tezlerde imlâ ve noktalama uygulamalarının incelendiği (Mataracı, E. 1998; Güneri, E.E. 2004; Kara, E. 2010) ve diğer çalışmalarda da öğretmenlerin ve öğretmen adaylarının noktalama kurallarını uygulama ve öğretimine ilişkin görüşlerinin araştırıldığı (Şahin, G. ve Topuzkanamış, E. 2008; Kurudayıoğlu, M. ve Dölek, O. 2018) görülmektedir. 
2010-2019 Yükseköğretime Geçiş Sınavlarında Noktalama İşaretlerinin Kullanımı Bilgisini Yoklayan Soruların incelenmesi

\section{Ortaöğretim Türkçe Programlarında Noktalama Ortaögrretim Dil ve Anlatım Dersi (9.,10.,11. ve 12.Sınıflar) Öğretim Programı (2011) Kazanımlarında Noktalama iş̧aretleri}

2011 Ortaöğretim Dil ve Anlatım dersi öğretim programında Ses Bilgisi ve Telaffuz (Söyleyiş) ünitesi 2. kazanımında "Yazı ile telaffuz ilişkisini gösterir." ibaresi yer almaktadır. Aynı kazanımın açıklamasında "Konuşma esnasında meydana gelen duraklamaların, soluk alıp vermeyle ilişkisi açıklanarak bunların yazı dilinde noktalama işaretleriyle karşılandığı belirtilir." ifadesiyle noktalama işaretlerinin yazım kılavuzunda yer alan tanımının uygulanması gerektiği belirtilmiştir.

Programda ayrıca her metin türü ile ilgili kazanım listesinde "... yazım ve noktalama işaretlerini değerlendirir." kazanımına yer verilmiştir. Programın ekleri arasında yer alan "Yazma alanında öğrenciyi değerlendirme formu"nda "yazımda imla ve noktalama kurallarına dikkat eder" ifadesi geçmektedir.

\section{Ortaögrretim Türk Dili ve Edebiyatı Dersi (9.,10.,11. ve 12.Sınıflar) Öğretim Programı (2018) Kazanımlarında Noktalama İsaretleri}

Ortaöğretim programları, yükseköğretime geçiş sınavları için temel çerçeve metin görevi görmektedir. Ülke genelinde tüm eğitimcilerin ulaşabildiği ve Türk Dili ve Edebiyatı dersi programını düzenlediği metin olan öğretim programları, dört yıllık lise eğitiminde öğrencilere verilmesi gereken bilgi ve beceriler konusunda öğretmenlerin rehberidir. Programda noktalama işaretlerine yalnızca yazma kazanımları içinde "B.10. Yazdığı metni gözden geçirir." kazanımının "a. Dil bilgisi, yazım ve noktalama bakımından gözden geçirmesi sağlanır." maddesinde yer verilmiştir. Ayrıca programda yer alan ünite, süre ve içerik tablolarında açılan dil bilgisi kısmında "Metinler üzerinden imla ve noktalama çalışmaları yapılır." ifadesi yer almaktadır. Bu hâliyle programda noktalama işaretlerinin kullanımına ve öğretimine dair belli bir yönlendirme yapılmamış, hâlihazırda sahip olunan bilginin metinler üzerinde çalışılması hedeflenmiştir.

\section{Yöntem}

Bu çalışma Türkiye'de yükseköğretime geçiş aşamasında kullanılan merkezî sınavlarda noktalama işaretlerinin sorgulanmasını inceleyen bir durum çalışmasıdır. Durum çalışması " 'Niçin' ve 'Nasıl' sorularını temel alan, araştırmacının kontrol edemediği bir olgu veya olayı derinliğine incelemesine olanak veren bir araştırma yöntemidir." (Yıldııım ve Şimşek, 2006; akt. Paker, 2017). Araştırmanın inceleme nesnelerini 2010-2019 yılları arasında yapıımış olan yükseköğretim kurumlarına geçiş sınavları oluşturmaktadır. Sınav sisteminin 2009 yılından sonra değişmiş olması (tek oturumda uygulanan ÖSS sisteminden çoklu oturumla uygulanan YGS-LYS sistemi) ve yeni öğretim programlarının uygulanması nedeniyle araştırmanın inceleme nesneleri 2010-2019 yılları arasında yapılan sınavlarla sınırlandırılmıştır.

Bu çalışmada bir veri toplama aracı olarak doküman incelemesiyle Türkiye'de yükseköğretim kurumlarına geçiş aşamasında uygulanan merkezî sınavlardan 2010-2018 yılları arasında yapılan "Yükseköğretime Geçiş Sınavı-Türkçe Testi", "Lisans Yerleştirme Sınavı 3 - Türk Dili ve Edebiyatı Coğrafya Testi", "2017 Temel Yeterlilik Testi - Türkçe Örnek Soruları", "2018 Temel Yeterlilik Testi Türkçe Testi", "2018 Alan Yeterlilik Testi Türk Dili ve Edebiyatı-Sosyal Bilimler 1", "2019 Temel Yeterlilik Testi - Türkçe" ile "2019 Alan Yeterlilik Testi Türk Dili ve Edebiyatı - Sosyal Bilimler 1" testlerinde noktalama işaretlerinin kullanımını ölçen soruların dağılımı ve ölçülmek istenen özellikleri incelenmiştir. Öncelikle bu sınavların uygulayıcısı olan Ölçme, Seçme ve Yerleştirme Merkezi (ÖSYM) Başkanlığı İnternet sayfasında yer alan sınav arşivinden ilgili sınavlara ulaşılmış, testlerde yer alan noktalama işaretlerinin kullanım bilgisini sorgulayan madde sayıları çıkarılmış, bu maddelerde hangi noktalama işaretlerine yer verildiği listelenmiştir. İncelenen 21 (yirmi bir) sınav içindeki noktalama işaretlerinin kullanımı ile ilgili soru sayısına ve noktalama işaretlerinin bu sorulardaki niceliksel yansımasına bakılmışır. Illgili soru tiplerinden örnekler verilmiş ve bu sorularla noktalama işaretlerinin kullanımı üzerine sahip olunan bilgilerin ölçülmesine ilişkin yorumlar yapılmıştır. 


\section{Bulgular \\ Noktalama Işsaretlerinin Ölçme Değerlendirme Uygulamaları}

Türkiye'de sınav yapan kurumların başında ÖSYM gelmektedir. ALES, KPSS, ÖSS, YGS, YKS gibi bir üst eğitim kurumuna geçiş, akademik eğitim alma, kamu memur alımları vb. amaçlarla uygulanan sınavlarla her yıl milyonlarca adaya ulaşılmaktadır. Yapılan sınavların kullanım amaçları ve ulaştıkları aday kitlesi düşünüldüğünde bahsedilen kurumun eğitim üzerinde büyük bir etkisinin olduğu söylenebilir. Her yıl milyonlarca öğrencinin girdiği yükseköğretime geçiş sınavları hem o yıl üniversitelerin öğrenci alımlarını etkilemekte hem de sınavın içeriği ile sonraki yıl sınava girecek olan aday kitlesinin hazırlıklarını şekillendirmektedir. Bu denli geniş kitleye hitap eden sınavlarda ölçme ve değerlendirme güçlüğünden dolayı çoktan seçmeli test soruları tercih edilmektedir. Ancak çoktan seçmeli soru tiplerinin noktalama işaretlerinin kullanımına dair bilgiyi sorgulamakta ne derece başarılı olduğu tartışmalıdır. Öğrencilerin bu soruları noktalama işaretlerinin kullanımı ile ilgili gerekli bilgilere sahip oldukları için mi şans başarısı ile mi doğru yanıtladıkları bilinememektedir.

2010-2019 Yılları Arasında Yapılan Yükseköğretim Kurumlarına Geçiş Sınavlarındaki Noktalama işaretleri Sorularında Yer Alan Işaretlerin Sayı ve Yıllara Göre Dağılımı*1

Tablo 1.

Noktalama İşaretlerinin Yıllara Göre Dağııımı

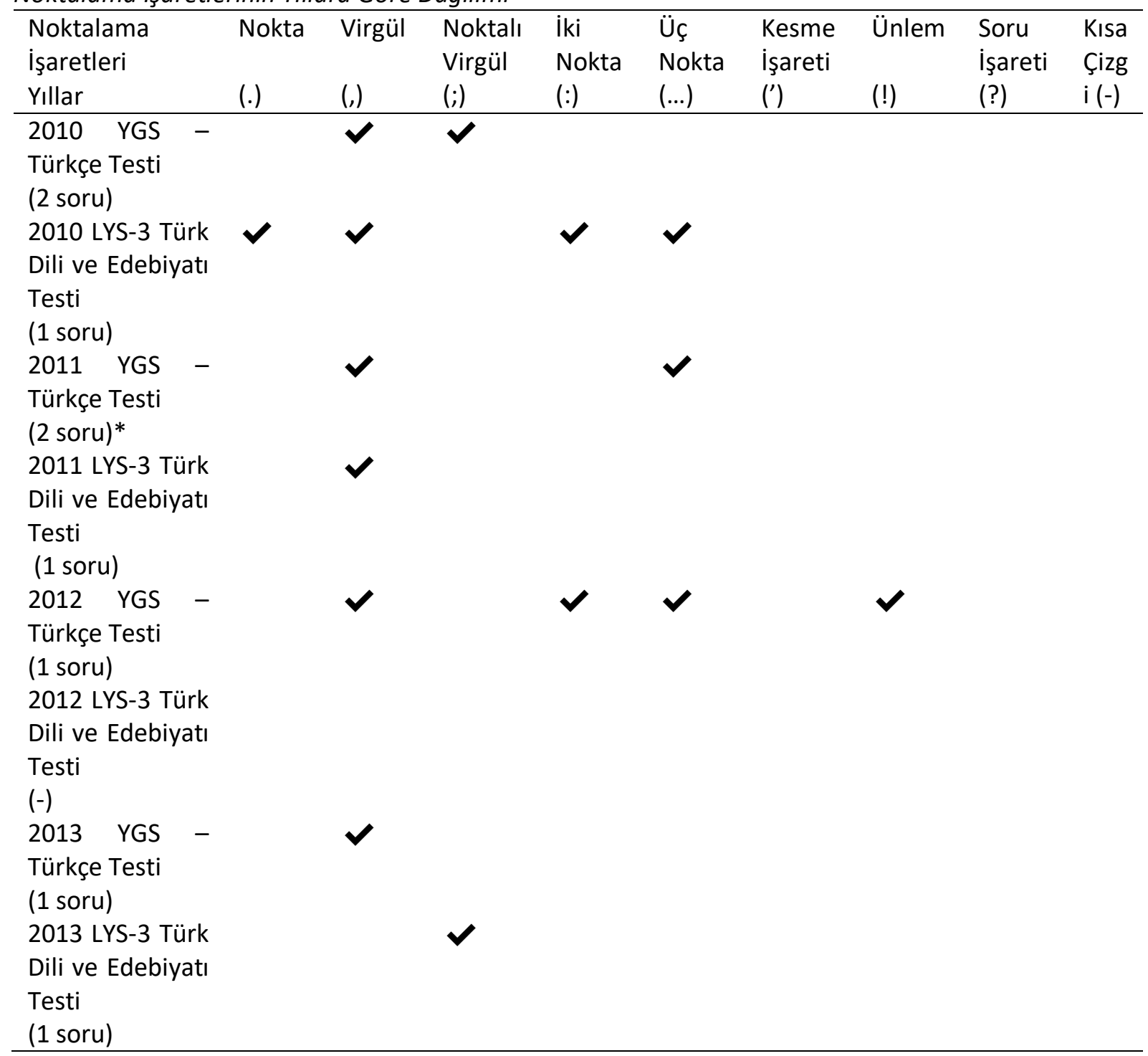

${ }^{1}$ Ölçme, Seçme ve Yerleştirme Merkezi Başkanlı̆ı̆ını 21 Mayıs 2018 tarihli duyurusu ile geçmiş yıllardaki sınav sorularının tamamı erişime açılmışıı. 
2010-2019 Yükseköğretime Geçiş Sınavlarında Noktalama İşaretlerinin Kullanımı Bilgisini Yoklayan Soruların incelenmesi

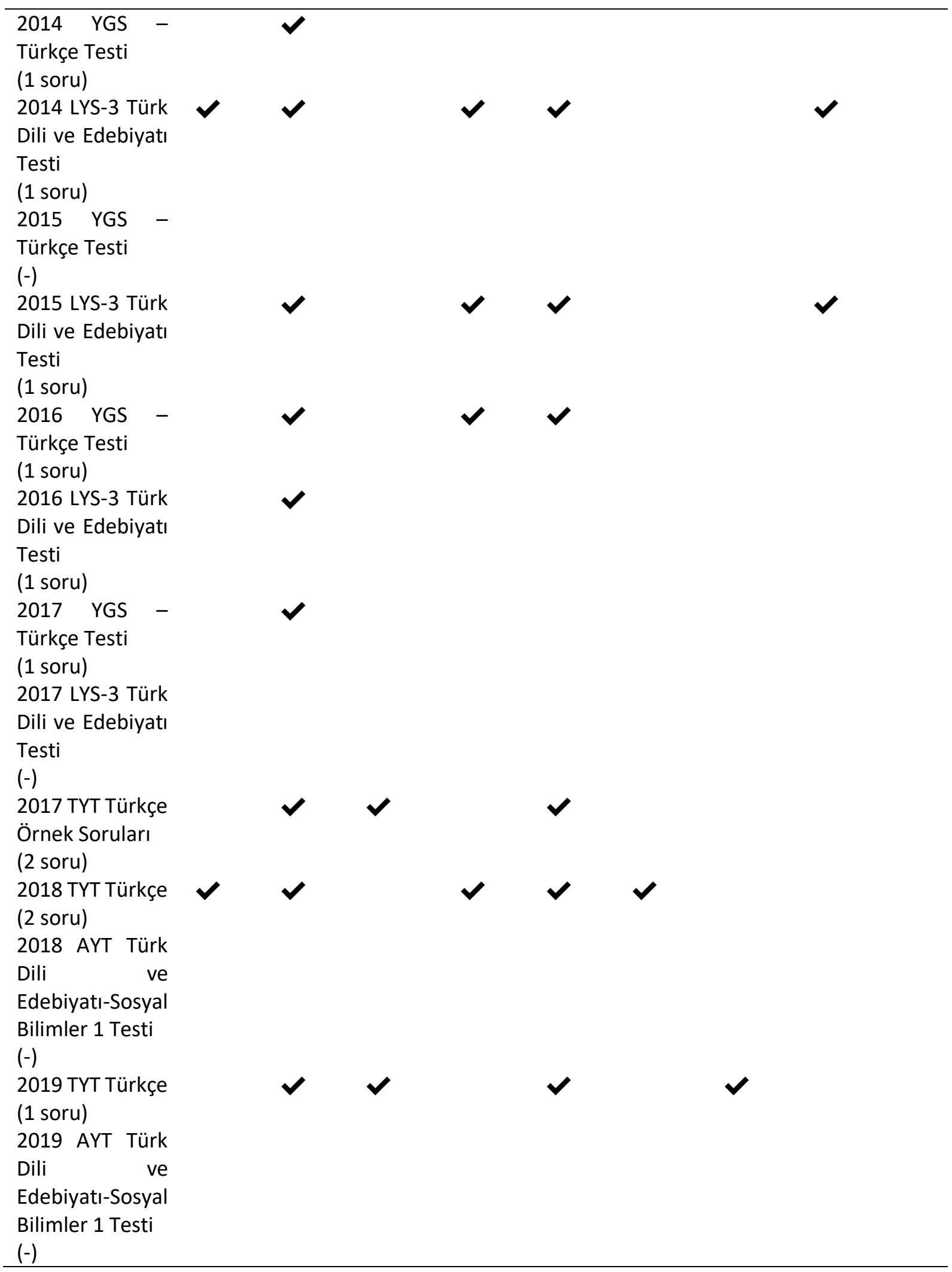


Tablo 2.

Noktalama Işsaretlerinin Sayıca Dağılımı

\begin{tabular}{|c|c|c|c|c|c|c|c|c|c|}
\hline $\begin{array}{l}\text { Noktalama } \\
\text { İşaretleri }\end{array}$ & $\begin{array}{l}\text { Nokta } \\
\text { (.) }\end{array}$ & $\begin{array}{l}\text { Virgül } \\
\text { (,) }\end{array}$ & $\begin{array}{l}\text { Noktalı } \\
\text { Virgül } \\
\text { (;) }\end{array}$ & $\begin{array}{l}\text { İki } \\
\text { Nokta } \\
\text { (:) }\end{array}$ & $\begin{array}{l}\text { Üç } \\
\text { Nokta } \\
(\ldots)\end{array}$ & $\begin{array}{l}\text { Kesme } \\
\text { İşareti } \\
\text { (') }\end{array}$ & $\begin{array}{l}\text { Ünlem } \\
\text { (!) }\end{array}$ & $\begin{array}{l}\text { Soru } \\
\text { İşareti } \\
\text { (?) }\end{array}$ & $\begin{array}{l}\text { Kısa } \\
\text { Çizgi } \\
(-)\end{array}$ \\
\hline Sıklık & 3 & 15 & 4 & 6 & 9 & 1 & 2 & 2 & - \\
\hline
\end{tabular}

2010-2019 yılları arasında yükseköğretime geçiş aşamasında kullanılan merkezî sınavlar incelenmiş olup bunlardan beşi hariç (2012 LYS-3 Türk Dili ve Edebiyatı Testi, 2015 YGS - Türkçe Testi, 2017 LYS-3 Türk Dili ve Edebiyatı Testi, 2018 AYT Türk Dili ve Edebiyatı - Sosyal Bilimler 1 Testi, 2019 AYT Türk Dili ve Edebiyatı - Sosyal Bilimler 1 Testi) her testte en az bir noktalama işareti sorusu olduğu görülmüştür (bkz. Tablo 1). Inncelenen yirmi bir sınavda en sık karşılaşılan noktalama işareti virgül olup noktalama işaretlerinin kullanımı ile ilgili soru içeren on altı sınavın on beşinde virgülün kullanım bilgisi sorgulanmıştır. Virgülü, dokuz kez ile üç nokta ve altı kez ile iki nokta takip etmektedir. Noktalama işaretlerinin kullanımı ile ilgili sorularda kısa çizginin kullanım bilgisine dair hiç soru sorulmazken kesme işareti bir soruda, ünlem ve soru işareti ikişer soruda sorgulanmıştır (bkz. Tablo 2).

2010-2019 Yılları Arasında Yapılan Yükseköğretim Kurumlarına Geçiş Sınavlarında Yer Alan Noktalama işaretleri Soru Tiplerine Örnekler

Bir parçada noktalama işareti gelecek yerin boş bırakıldığı; adayların seçeneklerde yer alan noktalama işaretlerinin hangilerinin uygun olduğunu seçmesi istenen sorular

Örneğin; 2019 TYT Türkçe Testi 17. Soru

Yeni aldığı ve çok sevdiği ayakkabısının bir teki futbol oynarken yırtılan çocuk ( ) ayakkabıcıya ( ) yeni ayakkabı bakmaya gitti. Ayakkabının üzerindeki fiyatı okudu. Bir an üzüldüğünü belli ederek vitrinden uzaklaştı. Durumu gören ayakkabıcı:

- Baktığın model sana çok yakışır ( ) denemek ister misin? Çocuk başını sallayıp:

- Üzerindeki fiyata göre almam mümkün değil ki ( ) Zaten bir tekini alacağım.

Dükkân sahibi: - Amma yaptın ha ( )

Bu parçada parantezle ( ) belirtilen yerlere, aşağıdaki noktalama işaretlerinden hangisi sırasıyla getirilmelidir?

a.) $(;)(),(),(!)(! \ldots)$

b.) $(),(;)(;)(\ldots)($.

c.) $(;)(),(),(\ldots)(!)$

d.) $(),(;)(),(!)($.

e.) $(;)($ ) (;) (.) (!..)

Bir parçadaki noktalama işaretlerinden hangisinin yanlış kullanıldı̆̆ını belirlemeye yönelik sorular Örneğin; 2017 YGS Türkçe Testi 17.soru

Büyük İskender... Kimileri , (I) onu insanlığın iyiliği uğruna zaferden zafere koşan bir ülkü adamı olarak görmüştür. Kimileri de davranışlarının, (II) nedeninin katıksız bencillik olduğunu, (III) ateşli tutkusunun onun yolunu aydınlattığını düşünmüştür. Bazıları, oynamış olduğu büyük oyunda sürdüğü her taşın , (IV) yaptığı her hamlenin ona muazzam bir zekâ tarafından dikte edildiği görüşündedir. Bazılarıysa onun, düşünmeden , (V) kendine çok güvenerek talihini güle oynaya izlediğine inanmıştır.

Bu parçadaki numaralanmış virgüllerden hangisi yanlış kullanılmıştır?
a.)!
b.)II
c.)III
d.)IV
e.)V

Belirli bir noktalama işaretinin bir parçada boş bırakılan yerlerden hangisine getirilebileceğinin ya da getirilemeyeceğinin seçilmesi istenen sorular

Örneğin; 2014 YGS Türkçe Testi 17.soru 
Bitpazarının girişinde duruyorsun. Birazdan bambaşka bir dünyaya dalacaksın. Sabahın erken saatlerinde gelmişler (I) tezgâhlarını dizmişler (II) geçmişlerinde ne var (III) ne yoksa bir bir sermişler. Sana da tuhaf gelmiyor mu, anılarına fiyat biçmiş olmaları? Burada çok dikkatli yürümelisin. Yanından geçeceğin küçücük oyuncağın bir düğmesinin bile öyküsü vardır, eşyaların seslerini duyacaksın (IV) bildiğin oyuncaklara benzemez bunlar (V) hepsi sahibinin sesini taşır.

Bu parçadaki numaralanmış yerlerden hangisine, herhangi bir noktalama işareti koymaya gerek yoktur?
a.) I.
b.)II.
c.)III.
d.)IV.
e.) V.

Üç farklı sınavdan örnek olarak alınan soru tiplerine bakıldığında her birinde, cümlede/metinde noktalama işaretlerinin kullanıldığı yerin soru yazarı tarafından adaylara verildiği görülmektedir. Olumlu ya da olumsuz soru köklerinde belirli bir noktalama işaretinin kullanım bilgisine ya da birden fazla noktalama işaretinin kullanılması ile metinsel bütünlüğü sağlamaya yönelik sorular hazırlanmıştır. Adayların bu üç soru tipinde de seçme/karar verme becerisini kullanması beklenmektedir.

Örnek soru tiplerinde de görüldüğü üzere sınavlarda adayların noktalama işaretlerinin hangi durumda ve metinde hangi noktalarda kullanılması gerektiği bilgisi sorulmamaktadır. Sorunun kendisinde noktalama işaretinin kullanılması gereken ya da kullanılmaması gereken yer imlenmiş olarak verilmekte, adaylardan ilgili yerlere hangi noktalama işaretinin/işaretlerinin getirilebileceği ya da getirilemeyeceği seçimi bırakılmaktadır. Bu şekilde sözlü anlatımın yazıda karşılığını göstermekten ve cümle bilgisinin uygulamada karşılı̆ıını bulmaktan çok noktalama işaretleri ile ilgili kitabî bilginin ezberlenmesi ile bu sorularda başarı sağlanması mümkündür.

\section{Tartışma, Sonuç ve Öneriler}

Türkçede noktalama işaretleri konusu ihmal edilmiş bir yazma alanı olarak karşımıza çıkmaktadır. Sözlü anlatımda yer alan boşluk, vurgu, durak gibi özelliklerin yazıda gösterilebilmesini sağlayan bu konunun yükseköğretime geçiş aşamasında kullanılan sınavlarda yer alan sorularda şans başarısıyla ya da sorulan işaretlerin cümlede boş bırakılan yerlere getirilip denenmesiyle cevabın bulunabileceği şekillerde sorulması noktalama işaretlerinin kullanım bilgisinin ölçülmesini tam anlamıyla yerine getirememektedir.

Örnek soru tipleri incelendiğinde sorularda genellikle noktalama işaretlerinin geleceği yerlerin soru yazarı tarafından belirlendiği ve öğrenciye ilgili yere hangi soru işaretinin getirilebileceği ya da getirilemeyeceği kararının bırakıldığı söylenebilir. Bu, bir bakıma, öğrencinin noktalama işareti kullanımından çok nerelerde zorunlu olarak kullanılması gerektiğini bilmesinin beklendiğini gösterir.

Noktalama işaretlerinin özellikleri ve kullanımı müstakil bir konu olmaktan ziyade cümle bilgisinden hareketle öğretilebilecek bir konudur. Ele alınan sınavlarda virgül ve noktalı virgülün kullanım alanlarının bir arada ölçülmesinin amaçlandığı soruların, cümle bilgisine başvurmadan doğru cevaba ulaşılamayacağı aşikârdır. Virgül ve noktalı virgülden hangisinin kullanılmasının uygun olduğu sorusunu cevaplayabilmek için cümle üzerinde çalışılmalıdır. Virgülün "Uzun cümlelerde yüklemden uzak düşmüş özneyi belirtmek için konur." (Yazım Kılavuzu, 2012: 28) gibi, noktalı virgülün "Cümle içinde virgüllerle ayrılmış tür veya takımları birbirinden ayırmak için konur." (Yazım Kılavuzu, 2012: 31) gibi görevleri ancak cümle bilgisi alanında yeterli bilgiye sahip olmakla ayırt edilebilecek kullanımlardır. Özellikle noktalı virgülün kullanım alanlarından; "Ögeleri arasında virgül bulunan sıralı cümleleri birbirinden ayırmak için konur, ikiden fazla eş değer ögeler arasında virgül bulunan cümlelerde özneden sonra noktalı virgül konulabilir." (Yazım Kılavuzu, 2012: 31) gibi görevlerini sorularda fark edip doğru kullanabilmek için adayların cümle bilgisine dair özellikleri biliyor olmaları gerekmektedir.

Noktalama işaretlerinin kullanımı ilköğretim yıllarından itibaren öğretilen bir konu olmakla birlikte ortaöğretim programında metinlerdeki yazım ve noktalama işaretlerinin kullanımı üzerinde durulmakta ve telaffuzun yazıda gösteriminin noktalama işaretleriyle sağlandığının fark ettirilmesi beklenmektedir (MEB, 2011). Yükseköğretime geçiş aşamasında kullanılan sınavlarda bu özellikler yoklanmasına rağmen kullanılan soru tiplerinde adayların şans başarısıyla doğru cevabı bulması mümkün olduğu için tam anlamıyla amaca ulaşamayacaktır. Her yıl 1 ya da 2 soru ile yoklanmaya 
çalışılan noktalama işaretlerinin kullanımı bilgisi farklı metinler üzerinde benzer noktalama işaretlerinin ve bunların benzer özelliklerinin sorgulanmasıyla gerçekleştirilmeye çalışılmaktadır. Hem aynı işaretlerin aynı özelliklerinin sorgulanması hem de şans başarısına yüksek oranda olanak sağlayacak ilgili noktalama işaretinin cümlede yer alacağı kısmın boş bırakıldığı soru tipleri ile adayların noktalama işaretlerinin hangi durumlarda ve cümlede/metinde hangi noktalarda kullanılması gerektiğini bildiğini varsaymak, bu bilgiyle soruları cevapladığını kabul etmek fazlaca iyimser bir yorum olacaktır. Noktalama işaretlerinin hangi durumlarda ve cümlede hangi noktalarda kullanılması gerektiğinin sorgulanması; cümle bilgisi ve noktalama işaretlerini sahih bir biçimde örnekleyebilecek bir metnin seçilmesi ve bu metinde kullanılacak noktalama işaretleri ile cümlelerde uygun alanların seçimi tamamen öğrenciye bırakıldığında ölçülebilir.

\section{Kaynaklar}

Aksan, D. (2015). Her yönüyle dil ana çizgileriyle dilbilim. Ankara: TDK Yayınları.

Aktaş, Ş. (2010). Dilin doğru ve güzel kullanımı üzerine. Türklük Bilimi Araştırmaları, 15(27), 37-42.

Alver, Ş. ve Sancak, M. (2015). Noktalama işaretlerinin ilköğretim II. kademe Türkçe dersi programlarına ve ders kitaplarına yansıması. International Journal of Language Academy, 3(1), 374-388.

Atasoy, F.O. (2010). Türkçede noktalama. İstanbul: Özel Kitaplar.

Atasoy, F. O. (2010). Noktalama işaretlerinin tarihi, Turkish Studies. 5(2), 823-860.

Bağcı, H. (2011). Illköğretim 8.sınıf öğrencilerinin noktalama işaretleri ile yazım kurallarını uygulayabilme düzeyi. Turkish Studies, 6(1), 693-706.

Talim ve Terbiye Kurulu Başkanlığı. (2011). Dil ve Anlatım Dersi 9., 10., 11. ve 12.Sınıflar Öğretim Programı. Ankara: MEB Yay.

Güneri, E.E. (2004). Ortaöğretimde (1.-3. sınıflar) noktalama işaretlerinin kullanımında, bilgi-beceri oranlarının tespiti (Yayımlanmamış yüksek lisans tezi). Afyon Kocatepe Üniversitesi Sosyal Bilimler Enstitüsü, Afyonkarahisar.

Kalfa, M.(2017). Başlangıçtan günümüze Türkçede noktalama. Ankara: Akçağ Yayınları.

Kara, E. (2010). Yazım, noktalama ve dil bilgisel beceri kazandırma bakımından 6.7.8.sınıf öğrencilerinin çalışma kitaplarının incelenmesi (Yayımlanmamış yüksek lisans tezi) Erzincan Üniversitesi Sosyal Bilimler Enstitüsü, Türkçe Eğitimi ABD, Erzincan.

Kurudayıoğlu, M. ve Dölek, O. (2018). Noktalama işaretlerinin öğretimine ilişkin öğretmen görüşleri. Mersin Üniversitesi Eğitim Fakültesi Dergisi, 14(1), 372-385.

Mataracı, E. (1998). İlköğretim okullarında I. kademe 5.sınıf öğrencilerinin imlâ ve noktalama işaretleriyle ilgili bilgi ve beceri düzeyleri (yayımlanmamış yüksek lisans tezi). Marmara Üniversitesi EBE Sınıf Öğretmenliği ABD

Talim ve Terbiye Kurulu Başkanlığı. (2018). Ortaöğretim Türk Dili ve Edebiyatı Dersi (9.,10.,11. Ve 12.Sınıflar) Öğretim Programı. Ankara: MEB Yay.

Özcan, Ş. ve Yönez, H.(2018). Ortaokul öğrencilerinin yazım kurallarını uygulama ve noktalama işaretlerini kullanma durumlarına yönelik bir inceleme. International Journal of Languages' Education and Teaching, 6(4), 541-558.

Özkara, Y. ve İzci, G. (2013). İlköğretim 5.sınıf öğrencilerinin okumaya yönelik tutumları ile noktalama işaretlerini uygulama düzeyleri arasındaki ilişkinin incelenmesi. Cumhuriyet International Journal of Education, 2(2), 1-9.

Paker, T. (2017). Durum çalışması. F. N. Seggie, Y. Bayyurt (Ed.), Nitel araştırma yöntem, teknik, analiz ve yaklaşımları (2.baskı) (ss.119-134). Ankara: Anı Yay.

Şahin, G. ve Topuzkanamış, E. (2008). Öğretmen adaylarının imla ve noktalama kurallarını uygulama düzeyleri üzerine bir araştırma, Balıkesir Üniversitesi Örneği. VII. Ulusal Sınıf Öğretmenliği Eğitimi Sempozyumu.

TDK (1941). Yazım kılavuzu (1941). Ankara: TDK Yayınları.

TDK (2012). Yazım kılavuzu (2012). Ankara: TDK Yayınları.

2010-2019 yılları arasındaki tüm yükseköğretime geçiş sınavları için bkz. https://www.osym.gov.tr/ 


\section{Extended Abstract \\ Introduction}

Language acts as a basic tool in regulating one's thinking system and providing interpersonal communication. It is possible for people to show what they are expressing by using punctuation. Punctuation guides the way the text is read, marks the ending of a sentence, pause, questions, surprise, anger. Punctuation rules allow the effect of speaking to be reflected to writing in a standardized manner. Academic studies on punctuation marks in Turkish generally aim to examine the use of punctuation marks of a certain group of students (such as the use of punctuation marks in the 8th grade students' written expression). The exams used in the transition phase to higher education institutions have a content that is shaped by the curriculum and they shape the preparatory phase of the students in the following years. For this reason, all topics and questions are important.

\section{Method}

This study is a case study examines the questions on punctuation in central exams for transition to higher education in Turkey. The study objects of the research are the transition exams held between 2010-2019. Examination system changed after 2009 and due to the implementation of new curriculums, the study objects of the research were limited to the exams held between 2010-2019. In this study, the central exams held in Turkey for transition to higher education were examined through document analysis as a method of data collection tool. The number of questions evaluating punctuation skills was removed and the punctuations asked in the questions were listed in the tests. The number of questions related to the use of punctuation marks and the quantitative reflection of punctuation marks on these questions were examined, as well.

\section{Result and Discussion}

In this study, distribution of the questions about punctuation marks in the higher education entrance exams between 2010-2019 was examined. Findings showed that at least one punctuation question was asked in 16 of the 21 exams conducted between those years, and for 5 years no punctuation question was included. Although a balanced question distribution was observed in terms of exams, punctuation marks which were examined were not balanced. In 15 of the 16 exams, where punctuation marks were used, questions related to the use of the comma were given, while one or two questions about apostrophe, exclamation mark and question mark were included. Nevertheless, whether the multiple choice question type was to use the knowledge of punctuation. In the multiple choice question type, either the area where the punctuation mark is placed in the text is left blank and the student is asked to choose only among the marks, or it is expected that one of the punctuation marks shown on a text is used incorrectly. In both cases, the student can reach the correct answer without analysing the text

The characteristics and usage of punctuation marks are not subject to individual subjects but rather can be taught by sentence knowledge. It is obvious that the correct answers cannot be reached without applying the sentence information to the questions aimed at measuring the usage areas of the comma and semicolon in the exams. The sentence should be studied in order to answer the question of which of the comma and semicolon is appropriate. The comma is "used to separate sequential sentences that are brought after the item that has fallen away from the predicate in long sentences; the semicolon functions used between sentences that have meaning in them but do not use conjunctions are those that can be distinguished only by having sufficient knowledge in the field of sentence knowledge. In order to realize and correctly use the tasks such as "used to separate commaseparated samples from different examples, to separate sequential sentences with comma arasında from the fields of use of semicolon, candidates should be aware of the characteristics of sentence information. The use of punctuation marks which are tried to be examined with 1 or 2 questions every year is tried to be realized by questioning similar punctuation marks and similar features on different texts. Assuming that you know the situations in which the punctuation marks should be used in the sentence / text and the points where the relevant punctuation mark will be included in the sentence, which will allow a high chance of success in both the same characteristics of the same signs, and the sentence / text in the sentence, it is more than acceptable to accept the questions. 